CRÍTICA, Revista Hispanoamericana de Filosofía

Vol. XXXI, No. 93 (diciembre 1999): 75-103

\title{
WITTGENSTEIN ON THE SOCIAL CHARACTER
} OF LANGUAGE*

\author{
Sílvio Pinto \\ Instituto de Investigaciones Filosóficas \\ UNAM
}

\begin{abstract}
A human being can encourage himself, give himself orders, obey, blame and punish himself; he can ask himself a question and answer it. We could even imagine human beings who spoke only in monologue; who accompanied their activities by talking to themselves. - An explorer who watched them and listened to their talk might succeed in translating their language into ours. (This would enable him to predict these people's actions correctly, for he also hears them making resolutions and decisions.)
\end{abstract}

Wittgenstein 1953, § 243

\section{Introduction}

Wittgenstein's claim in paragraphs 241 and 242 of the Philosophical Investigations ${ }^{1}$ that agreement in their language is a necessary condition for success of verbal communication among human beings seems hardly congruent with his contention in the following paragraph that there could

* An earlier version of this paper was delivered at the XIV Interamerican Philosophy Congress at the University of Puebla in August 1999. I am grateful to Claudia Lorena García, Salma Saab and Meredith Williams for their very helpful comments.

1 Wittgenstein 1953. Henceforth, this will be referred to as the Investigations. 
be a non-social linguistic practice - that exemplified by the monologue people. In this paper, I will attempt to reconcile his two claims by examining the question of where, for Wittgenstein, the role of the social in the philosophical explanation of our linguistic skills lies. This investigation will concentrate on the celebrated rule-following considerations. It will contend that the mentioned role emerges from Wittgenstein's remarks about what constitutes following a rule and what the nature of our access to rule-following is.

\section{The Rule-Following Considerations}

Deviant rule-followers and non-standard users of familiar words, possibilities advanced by Wittgenstein and others who have followed his lead, appear to be too fictional to deserve serious philosophical inquiry. The famous example of the Investigations is that of a person who associates the sign '+ 2' with the content add 2 up to 1000, 4 up to 2000, 6

up to 3000 and so on. ${ }^{2}$ Kripke's case of the quadder ${ }^{3}$ - the individual who is like any normal English speaker except in that he uses the sign ' + ' to denote quaddition ${ }^{4}$ rather than addition - is but a variation on the Wittgensteinian theme. The two examples may be very far-fetched but they raise an important problem, a problem that Kripke calls skepticism about meaning and that in the Investigations corresponds to the problem of explaining rule-following. They are basically, as I will show, the same problem formulated differently by the two authors. Kripke conceives the skeptical problem about meaning as consisting of a constitutive and an epistemological requirement, which can be expressed by means of the following questions: a) what

2 Wittgenstein 1953, § 185.

${ }^{3}$ In Kripke 1982, pp. 8-9.

${ }^{4}$ I.e., the function which is like addition for all arguments less than 57 and whose result is 5 otherwise. 
fact about the subject $(S)$ constitutes his using the sign '+' to add rather than to quadd? (constitutive requirement); b) how does this meaning-constituting fact justify $S$ in judging that he is an adder rather than a quadder? (epistemological requirement). ${ }^{5}$ I take it that Kripke would not object to this more neutral and more general formulation of (a) and (b): $\left.a^{\prime}\right)$ what constitutes linguistic meaning? $b^{\prime}$ ) how are we justified in our beliefs about the content of the words in our idiolects? ${ }^{6}$ Any solution to the meaning skeptical problem must therefore satisfy these two conditions (or requirements): $\left(\mathrm{a}^{\prime}\right)$ and $\left(\mathrm{b}^{\prime}\right)$.

We find Wittgenstein struggling with the constitutive question about rule-following - the notion in terms of which he attempts to explain meaning - in paragraph 186 of the Investigations immediately after the possibly deviant rule-follower is introduced. The question being discussed is what constitutes the standard of correctness for the activity of following a rule. Consider, for example, the following extract from paragraph 186:

How is it decided what is the right step to take at any particular stage? - "The right step is the one that accords with the order-as it was meant." - So when you gave the order +2 you meant that he was to write 1002 after 1000 - and did you also mean that he should write 1868 after 1866, and 100036 after 100034, and so on - an infinite number of such propositions?- - No: what I meant was that he should write the next but one number after every number that he wrote; and from this all those propositions follow in turn."-But that is just what is in question: what, at any stage, does follow from that sentence. Or, again, what, at any stage we are to call "being in accord" with that sentence (and with the mean-ing you then put into the sentence-whatever that may have consisted in). (Wittgenstein 1953, § 186)

${ }^{5}$ See Kripke 1982, p. 11.

${ }^{6}$ Kripke 1982, pp. 12, 23. 
We will be concerned with Wittgenstein's answer to the constitutive question about rule-following below. Now, let us look for evidence that he sees also an epistemological dimension to the problem of explaining rule-following. Some remarks from the Investigations strongly suggest that the nature of our epistemic access to the activity of following linguistic rules must also be elucidated. For instance, these two:

"How am I able to obey a rule?"-if this is not a question about causes, then it is about the justification for my following the rule in the way I do. (Wittgenstein 1953, §217)

Suppose you came as an explorer into an unknown country with a language quite strange to you. In what circumstances would you say that the people there gave orders, understood them, obeyed them, rebelled against them, and so on? (Wittgenstein 1953, §206)

Each of these quotations presents the epistemological aspect of rule-following from a different perspective: in the first, this aspect is expressed in the first-person perspective, whereas the second citation contains a third-person formulation of the epistemological question concerning rulefollowing. According to Wittgenstein, there would be no solution to the problem of our access to linguistic meaning and rules if separate and asymmetric accounts could not be provided for first-person and third-person knowledge of the content of our words. This will become clearer below.

So, it is, I would suggest, useful to distinguish in the problem discussed in paragraphs 138-243 of the Investigations a constitutive and an epistemological question. Moreover, the latter question must be further split into two sub-questions: that of our first-person and the question of our third-person access to linguistic rules.

Many people have interpreted Wittgenstein as claiming that the subjective/objective distinction for rule-following 
- that between actually following a rule and merely thinking one is following a rule- can only be drawn if we appeal to the notion of a social practice. The distinction - suggested by Wittgenstein as a criterion of adequacy for candidate answers to the constitutive question- cannot be accommodated by accounts which conceive of rulefollowing and of meaning as private activities. This is the lesson to be learned from the famous paradox which results from the conception of rule-following as the activity of interpreting one's own spoken, written or mental word. This is how he describes the paradox and the conception that gives rises to it:

no course of action could be determined by a rule, because every course of action can be made out to accord with the rule. The answer was: if everything can be made out to accord with the rule, then it can also be made out to conflict with it. And so there would be neither accord nor conflict here.

It can be seen that there is a misunderstanding here from the mere fact that in the course of our argument we give one interpretation after another; as if each one contended us at least for a moment, until we thought of yet another standing behind it. What this shows is that there is a way of grasping a rule which is not an interpretation, but which is exhibited in what we call "obeying the rule" and "going against it" in actual cases.

Hence there is an inclination to say: every action according to the rule is an interpretation. But we ought to restrict the term "interpretation" to the substitution of one expression of the rule for another. (Wittgenstein 1953, § 201)

But the reductio of privatist approaches to rule-following does in no way necessitate the social approaches if these latter are to be seen as implying that there must be something which is shared by the speakers: their linguistic dis-

7 See also paragraph 198 for a similar formulation of the paradox. 
positions, conventions or practices. A social account of the latter kind is that which came to be known as the community view. ${ }^{8}$ According to the proponents of the community view, the linguistic use of a member of a community provides the objective standard for how someone should employ words. For the communitarian theorist, correctness is identified with acting in the presence of, and reacting to, words in the same way as someone else (a member of the linguistic community). We will return to this point at the end of section 4 .

It is true that within the community view there is room for the objective/subjective distinction with respect to rulefollowing. And if this view was to offer the correct answer to the problem of rule-following there could be no speaking of a language outside the context of the other speakers of the same language. For without at least a second person to supply the standard, there would be, according to the communitarian theorist, no criterion for evaluating the solitary speaker's use of words as correct or incorrect. But does Wittgenstein endorse the community view with its indispensably social notion of a linguistic norm?

I think the majority of the contemporary commentators would agree that he rejected the communitarian explanation of meaning and rule-following. The evidence commonly cited in support of this exegetical claim comes from paragraph 241 of the Investigations and from paragraph 40, part VII, of the Remarks on the Foundations of Mathematics ${ }^{9}$ wherein he denies that agreement in empirical judgement among human beings constitutes the objective pattern concerning the use of words. Wittgenstein's refusal to countenance the communitarian account of what consti-

8 The pioneering communitarian theorists were Crispin Wright (1980) and Kripke (1982).

9 Wittgenstein 1978. Henceforth, the Remarks. 
tutes meaning creates a double puzzle: on the one hand, one may wonder whether there could be an intermediate position between the privatist and the communitarian approaches to rule-following; on the other hand, there seems to be an inconsistency between Wittgenstein's dismissal of the communitarian standard of objectivity for linguistic use - agreement in judgement - and his claim ${ }^{10}$ that linguistic communication requires agreement in judgement.

\section{The Later Wittgenstein and the Interpretive Framework}

Let us start with the first part of the puzzle: the question of whether there is a stable midway position between privatism and the community view. It seems to me there is a way of reading Wittgenstein which places his account between the above two views. I am referring to the idea first put forward by Jim Hopkins ${ }^{11}$ of seeing Wittgenstein's later remarks as suggesting a radically interpretive view of sorts. Hopkins has highlighted the similarities between the position of the later Wittgenstein and Davidson's interpretive perspective. I have summarized these elsewhere. ${ }^{12}$ For my purposes here, it is worth reviewing some of the features of the radically interpretive approach that I will be attributing to Wittgenstein.

The central tenet common to all interpretive accounts of human intentional behavior is that the attribution of mental items such as meaning, belief and desire results from the process of formulating empirical hypotheses whose basis is what the speaker says and does. These hypotheses must serve a three-fold purpose: a) they must cover the regularities observed in the speaker's behavior; b) they must

10 Wittgenstein 1953, § 242.

11 In Hopkins 1995.

12 In Pinto 1998, chapter 3. 
be such as to permit one to predict the subject's future behavior; c) and finally they must provide an explanation of his behavior as couched on reasons. This last purpose amounts to the idea that the mental items hypothesized as linked to the behavior of a speaker must contribute to our seeing him as an intentional and rational agent. That is, these mental items must provide the norms by which the behavior of the speaker, described as intentional actions, can be assessed as agreeing or conflicting with the mental features it makes sense to ascribe interpretively to him. It is absolutely essential for the eventual success of the method of interpretation that there is enough regularity in the conduct of the subject (or subjects), a regularity of a kind that could be grasped by a suitably equipped interpreter. According to Wittgenstein, the kind of regularity in question must obtain between what the interpretee says (the sounds he emits) and what he does (the actions with which he accompanies these emissions). Thus, consider what Wittgenstein says about the explorers - suppose that we were such explorers - who go to a foreign land and encounters a tribe speaking what looks like a language:

Let us imagine that the people in that country carried on the usual human activities and in the course of them employed, apparently, an articulate language. If we watch their behavior we find it intelligible, it seems 'logical'. But when we try to learn their language we find it impossible to do so. For there is no regular connection between what they say, the sounds they make, and their actions; but still these sounds are not superfluous, for if we gag one of the people, it has the same consequences as with us; without the sounds their actions fall into confusion - as I feel like putting it.

Are we to say that these people have a language: orders, reports, and the rest?

There is not enough regularity for us to call it "language". (Wittgenstein 1953, §207) 
Let me illustrate these points through one of Wittgenstein's own examples. Think of the most primitive language-game of the builders. ${ }^{13}$ Their language consists only of orders, none of which is articulated; all their orders are utterances of one-word sentences. Whenever builder $A$ wants builder $B$ to hand him one of the four building materials - blocks, pillars, slabs or beams - he shouts the item's respective English word to $B$, who goes to the pile and brings it to $A$. An interpreter observing their behavior might see causal regularities like the following:

(C) Whenever $A$ emitted such and such a sound $B$ did so and so.

Similar behavior by other members of the builders' community might support the following further generalization:

(H) For any two members of the builders' community $X$ and $Y$, if $X$ utters such and such sequence of words in the presence $Y$, then $Y$ does so and so.

Further observation of the deeds of the builders - for example, gestures of disapproval by one builder after another brought him the wrong building item - might prompt the interpreter to put forward this rational explanation of their behavior:

(E) $Y$ does so and so in these circumstances - for example, he brings such and such building item- because for him this sequence of words means the order to do so and so.

Now, if the language-game of the builders has any similarity with our complex languages, as Wittgenstein believed, and if a certain interpretive framework can be applied both to their situation and to ours, as I will argue

13 Wittgenstein 1953, $\S \S 1-10$. 
below, then his picture of how the phenomenon of speaking a language could be explained becomes a bit clearer. The first step of Wittgenstein's interpretive method is that of a spectator's observing regularities like $(\mathrm{C})$ in the behavior of the aliens. The interpreter (or spectator) then proposes empirical hypotheses like $(\mathrm{H})$ to cover these regularities. And finally, from the set of hypotheses best confirmed by the evidence of the subjects' behavior, the interpreter goes on to infer the linguistic norms that govern their language and hence the speakers' mçeanings, intentions and purposes, that is, the mental elements that are apt to make the best sense of their linguistic behavior as intentional. But what is it that justifies the interpreter's leap from hypotheses like $(\mathrm{H})$ to the linguistic norms of the aliens' language?

The very formulation of $(\mathrm{H})$ suggests that the evidence observed by the interpreter is already intentional. This might raise the objection that interpretation presupposes what it set out to explain, namely: intentional states such as those of meaning, believing or desiring. Wittgenstein seems to think that some basic intentional behavior can be observed immediately. Thus, in an investigation of possible cases from which it could be said that someone is playing a game according to a rule, he mentions the following possibility:

One learns the game by watching how others play. But we say that it is played according to such-and-such rules because an observer can read these rules off from the practice of the game - like a natural law governing the play.-But how does the observer distinguish in this case between players' mistakes and correct play?-There are characteristic signs of it in the player's behavior. Think of the behavior characteristic of correcting a slip of the tongue. It would be possible to recognize that someone was doing so even without knowing his language. (Wittgenstein 1953, § 54) 
Wittgenstein is never more explicit than this about the basic intentional behavior of the aliens that could be grasped non-inferentially by an interpreter without detailed knowledge of the player's intentions, purposes and all his other complex attitudes. However, if he is right about the existence of observable intentional behavior and if knowledge of such a behavior does not presuppose previous knowledge of the language of the speakers, then there is no risk that the present interpretive framework will beg the question that it proposed to answer: the question of accounting for the contents of the aliens' words and for their attitudes towards these contents. There is no such risk because the mentioned observable intentional behavior constitutes the evidential basis from which the more complex intentional states of the subjects (those that possess a propositional content) are inferred interpretively. The question ${ }^{14}$ of the justification for the interpretive leap from the empirical hypotheses linking the linguistic and non-linguistic behavior of the speakers to the norms of their language can then be answered in the following way: seeing their behavior as intentional is what best fits and explains the evidence and also leads to the most accurate prediction of their future behavior.

Let me gather more textual evidence in support of the interpretive reading of Wittgenstein. The character of the radical interpreter makes his appearance in Wittgenstein's later work in various passages; one of the most striking references to the foreign explorer - the person whose task is to understand the language of an alien group of speakersoccurs in the sequence of aphorisms following the famous claim that following a rule is also a practice. ${ }^{15}$ In the above-

14 Raised three paragraphs above.

15 Other passages are paragraphs 32, 54, 207 and 243 of the Investigations, as well as paragraph 48, part VI, of the Remarks (1978). 
quoted paragraph 206, after raising again the constitutive question concerning rule-following, Wittgenstein suggests that the way to cast light on this question is to take the perspective of someone who comes across a foreign group of seeming speakers. He then poses the question of what criteria an interpreter could use to judge whether the noises the speakers produce constitute a language. The answer comes in the following sentence: "the common behavior of mankind is the system of reference by means of which we interpret an unknown language". ${ }^{16}$ If this remark is to cohere with its antecedents - especially with 202-17 and with its consequents — more specifically with $208-18$ then the term 'common behavior of mankind' must be referring to our interpretable linguistic practices.

All this is of course not to say that there are no differences between Wittgenstein's and Davidson's respective interpretive approaches. Davidson has been much more explicit about what his interpreter has to know in order to be able to interpret someone else and also about how the interpreter comes to have that knowledge. According to him, the radical interpreter must be in possession of an unified theory consisting of an empirically adequate theory of truth a la Tarski ${ }^{19}$ — whose role is to impose a structure on the meanings of the speaker's words - plus a version of Ramsey-Jeffrey's decision theory ${ }^{20}$ — whose job is to gauge

16 Wittgenstein 1953, § 206.

17 Where he claims that following a rule is also a practice.

18 Where he says that in order to get someone to grasp a new concept we have to initiate him in a certain linguistic practice; we will give him examples and oversee that he gets the concept right by expressing agreement or disapproval of what he does.

19 Tarski's theory is expounded in Tarski 1933.

20 Jeffrey's refinement of Ramsey's theory is presented in Jeffrey 1965. Ramsey's luminous insight was to have found a solution to the problem of how to work out the belief and desire patterns of a subject 
the attitudes of the speaker and his meanings. The version of decision theory favored by Davidson requires a slight modification to the theory of decision put forward by Jeffrey: the primitive notion in Davidson's version of the theory is that of a preference between the truth of two sentences, ${ }^{21}$ instead of that of a choice between gambles (Ramsey) or that of a preference between propositions (Jeffrey). The condition of empirical adequacy on the theory of truth states that the totality of its T-sentences must optimally fit the set of sentences held by the speaker to be true. Davidson's unified theory of interpretation will be tested against the following data: the temporal evolution of the whole scale of the speaker's preferences for the truth of the sentences of his language. ${ }^{22}$

It is worth noticing that Davidson's interpreter is none of us; the evidence at his disposal differs a great deal from the evidence we bring to bear on our normal understandings of one another. Nor is it plausible to suppose that we actually apply anything like the unified theory in the course of our communicative exchanges with other people. The Davidsonian interpreter is an abstraction; its point, as his author admits, is the performance of a thought experiment designed to articulate the philosophically relevant features of concepts like meaning and the propositional attitudes. ${ }^{23}$ The thought experiment can be described as follows. We do not know by what means human beings find meaning and motive in other human beings. Suppose nonetheless that someone — call him $D$ - knew a unified theory for a certain

from his observable scale of preference for various wagers. Ramsey's theory is expounded in Ramsey 1926.

21 This is in Davidson 1980, pp. 8-9; Davidson 1982, pp. 8, 13-14, and Davidson 1990, pp. 322-323.

22 Davidson 1995, pp. 9-10.

23 Davidson 1995, p. 10. 
group of speakers; suppose $D$ succeeded in building this theory from the omniscient observation of the speakers' complete scale of preferences for the truth of sentences. Then $D$ would be able to interpret these speakers.

Wittgenstein's interpreter is not as dissimilar to ourselves as is Davidson's interpreter. A useful way to picture the former is to think of him as more like Quine's linguist or radical translator. ${ }^{24}$ Quine's linguist faces the task of elaborating a translation manual from the alien speakers' language $\left(L_{S}\right)$ to his own language $\left(L_{I}\right)$ on the basis of their observable behavior. The radical translator must derive the similarity (perhaps sameness) of meaning between the sentences of $L_{S}$ and the sentences of $L_{I}$ from the stimulus which, according to the translator, causes their assenting to, or dissenting from, the $L_{S}$-sentences. This points to the common feature of interpretive approaches I have already mentioned, namely, that interpretive hypotheses —in Quine's specific case, synonymy hypotheses - rely on causal regularities present in the linguistic behavior of the speakers. Another characteristic upon which interpretive theorists coincide is in considering the evidence available to the interpreter as already intentional. Quine, for example, chooses assent to, and dissent from, sentences as part of the evidence upon which his linguist relies.

A matter of difference between Quine and Davidson as regards radical interpretation concerns the form of the apparatus, the possession of which would allow the interpreter to find his way into the alien language. For Quine, such an apparatus is a translation manual that would match not only the sentences of $L_{S}$ with their synonymous counterparts in $L_{I}$ but also some terms of $L_{S}$ - for example, its logical constants. However, in the case of $L_{I}$ 's apparatus for reference and quantification — say, its identity and quan-

24 To be found, for instance, in Quine 1960, chapter 2. 
tification operators - there may be, according to Quine, no synonymous terms in the foreign language. A reason for this may be that the formal tools for reference and predication cannot be applied to such a language. Quine himself claims that these tools are exclusive of conceptual schemes like ours. ${ }^{25}$ He thinks, however, that the truth-conditional apparatus must be present in all languages; otherwise it would be impossible to translate a foreign language into ours. $^{26}$

Wittgenstein's interpreter, as I have noted, is much more akin to Quine's linguist than to Davidson's interpreter. Unlike the third, neither of the first two needs to be in possession of a recursive theory of interpretation in order to be in a position to understand their respective subjects. Thus, it is not quite clear how the translation manual would systematically relate the meanings of whole sentences of the foreign language with those of their corresponding subsentential expressions, since that language may lack the quantificational and referential machinery we find useful to describe our own language. Wittgenstein suggests that the possession of sufficiently many interpretive hypotheses about his interpretees may allow the foreign explorer to infer their language-game much like observing a game being played might lead the watcher to recognize that game -i.e., to identify the rules governing the game. ${ }^{27}$ But there is no hint in Wittgenstein's later writings that the best hypotheses gathered by the foreign explorer to interpret other people would constitute an as systematic apparatus as the recursive, finitely axiomatized theories concocted by David-

25 See Quine 1960, p. 53.

${ }^{26}$ Those familiar with Quine know that his argument here makes essential appeal to the principle of charity. More on it in Quine 1960, chapter $2, \S 13$.

27 As Wittgenstein suggested in the last quotation. 
son's interpreter. This may also explain why Wittgenstein is not as precise as Davidson about the kind of evidence that would serve to confirm or undermine the interpretive hypotheses advanced by Wittgenstein's explorer. The detailed specification of the theoretical machinery at the disposal of his interpreter forced Davidson to be explicit about what evidence could corroborate or disconfirm such a theory.

Commentators have usually dismissed the interpretive reading of Wittgenstein on the basis of his resolution of the celebrated paradox of rule-following, which finds its most compelling expression in paragraph 201: if following a rule was exclusively an interpretation then there would be no accord or conflict with a linguistic rule; no objective/subjective distinction could be drawn with respect to judgements as to whether the subject is following a rule or not. In paragraphs 201 and 202, Wittgenstein seems to be rejecting the view that following a rule is an activity of interpreting an instruction one gives to oneself in the sense of substituting one expression of the instruction for another. I think the appearance of incompatibility between 201-202 and 206, the paragraph in which he claims that "the common behavior of mankind is the system of reference by means of which we interpret a foreign language", is dispelled if we distinguish two senses of interpretation, both of which, in my opinion, are present in the Investigations: the first-person and the third-person interpretation. What Wittgenstein opposes is the idea that rule-following could be exhaustively explained in terms of the activity of interpreting in the first person, that is, the activity of substituting one's own words by other words or substituting the expression of the instructions one gives to oneself by another. He is thereby not dismissing the claim that interpretation in the third person - that is, the formulation 
of hypotheses by an observer about the behavior of the rule-follower- is useful in accounting for rule-following.

In paragraph 198, for example, Wittgenstein says that interpretation cannot on its own determine meaning. This holds for both first-person and third-person interpretation. First-person interpretation is not sufficient for determining meaning because, as the paradox of rule-following shows, there could be no correct or incorrect use of words if meaning was solely constituted by first-person interpretation. The reason why Wittgenstein thinks that third-person interpretation cannot on its own constitute meaning is that no matter how some bit of the linguistic behavior of a speaker is interpreted by his hearer there are many alternative sets of interpretive hypotheses that would accommodate equally well that behavior. ${ }^{28}$ If that is so, then what would suffice to determine meaning? Wittgenstein's answer to this question has already been given above: linguistic meaning is determined by our linguistic practices. But it must be possible for these practices to be observed and interpreted by someone else; otherwise there could never be objective judgements as to whether somebody uses a word correctly or not. So, what, according to Wittgenstein, complements third-person interpretation is the more primitive access to meaning and linguistic rules which is exclusive of the firstperson: the subject's practical grasp of a rule. Only when rule-following is pictured as a complex process involving two actors - the rule-follower and his interpreter- can we hope to get rid of the paradox so forcefully described in paragraph 201. If a certain harmony between these two actors obtains such that interpretation succeeds (that is, if the interpreter understands the rule-follower as the latter intended to be understood), their respective practical

28 Besides $\S 198$ of the Investigations, see also $\S \S 28,30 \mathrm{n}, 32,34$, 71 and 85. 
and interpretive accesses to the meaning of the words of the rule-follower will yield the desired solution to the epistemological puzzle, and therefore also to the constitutive puzzle, surrounding rule-following. ${ }^{29}$

\section{The Distinction between the Communitarian and the Interpretive Frameworks}

It was claimed in the previous section that the interpretive framework represents an intermediate position between the privatist and the communitarian approaches to meaning. We are now in a position to see how this is so. Remember that the privatist believes that the perspective of the first-person suffices to solve the problem of rule-following. Thus, privatists like Descartes ${ }^{30}$ and Colin McGinn ${ }^{31}$ say that introspection gives us privileged access to the meanings of the words in our idiolects - the semantical facts about ourselves. They would claim that introspection on its own can silence Kripke's meaning skeptic ${ }^{32}$ or dodge Wittgenstein's regress of first-person interpretations. ${ }^{33}$ The problem with the introspective access to meaning, and to the mental in general, is that it does not provide us with an objective standard for the attribution of meaning. As Wittgenstein puts it, the privatist answer to the epistemological question about rule-following renders the distinction between following a rule and merely thinking one is following a rule impossible to draw. ${ }^{34}$ First-person grasp of meaning facts of the sort that the privatist postulates

29 I developed this in more detail in Pinto 1998, chapter 3, sections 3.4.1 and 3.4.2.

30 In his Meditations (Descartes 1641).

31 For instance, in his book on Wittgenstein (McGinn 1984).

32 Introduced in Kripke 1982.

33 Wittgenstein 1953, § 201.

34 Wittgenstein 1953, $\S \S 201-202$. 
blurs the objective/subjective divide with respect to meaning avowals. Let us call this requirement that the account of meaning produces an objective pattern for meaning attribution Wittgenstein's constitutive condition.

Many people thought that the only plausible alternative to the privatist approach which satisfies Wittgenstein's constitutive condition is the community view. According to the communitarian theorist, a judgement "person $A$ means such and such by the word " $w$ " " as uttered by $B$ (a member of a linguistic community) is true if $A$ uses 'w' as $B$ would also use ' $w$ ' in the same circumstances. Thus, with respect to the word 'plus' as used by a speaker he calls Jones, Kripke says:

Smith will judge Jones to mean addition by 'plus' only if he judges that Jones's answers to particular addition problems agree with those he is inclined to give [...]. If Jones consistently fails to give responses in agreement $[\ldots]$ with Smith's, Smith will judge that he does not mean addition by 'plus'. Even if Jones did mean it in the past, the present deviation will justify Smith in judging that he has lapsed. (Kripke 1982, p. 91)

The introduction of an external perspective to that of the language user - the perspective of the third person-does make the relevant difference. It may be that Smith mistakenly judges Jones to mean so and so by ' $w$ '; it may also be that Jones means so and so by ' $w$ ' although Smith judges him to mean something else. In both cases, Smith's meaning attributions to Jones require revision. The communitarian standard of objectivity with respect to meaning can also be described like this: ' $w$ ' means such and such for Jones if his uses of ' $w$ ' coincide with the way a member of the community (Smith) would use this word in similar circumstances. Meaning for the community view is constituted by the responses (or judgements) of a member of a linguistic 
community. If Jones has the same linguistic dispositions as Smith then Jones means what Smith's community means by its words.

But what is it that the members of the community to which Smith belongs mean by their words? What makes the judgements of a certain English community regarding the use of the word 'plus' the correct judgements? Many opponents of the community view have recurrently insisted that no good answer to these questions can be extracted from the communitarian notion of the objectivity of semantical discourse. They have complained that the communitarian theorist has replaced the old view of concepts as authoritative independently of our judgements with a very thin notion of the objective patterns we must follow when speaking a language. The following passage from John McDowell expresses the point clearly:

it is only going out of step with one's fellows that we make room for; not going out of step with a ratificationindependent pattern that they follow. So the notion of right and wrong that we have made room for is at best a thin surrogate for what would be required by the intuitive notion of objectivity. That would require the idea of concepts as authoritative; and the move away from idiolects has not reinstated that idea. (McDowell 1984, p. 328)

I do not intend to enlarge on this objection here not least because it does not, in my opinion, do full justice to the community view. One cannot deny, however, that the communitarian linguistic norms are unavoidably judgementdependent. This is what this objection so clearly emphasizes.

We know that Wittgenstein rejected the community view. But how does the interpretive approach attributed to him here distinguish itself from the communitarian one? What he says in paragraph 241 of the Investigations - namely, 
that agreement in judgement is a condition of possibility of linguistic norms - seems to suggest an account of norms that is both judgement-dependent and social. Let us examine the issue more carefully. Right after the disturbing remark about agreement in judgment, Wittgenstein proposes an analogy, familiar to those who have read his 39Cambridge Lectures, ${ }^{35}$ the analogy between a language and the techniques of measuring. This is what he says:

If language is to be a means of communication there must be agreement not only in definitions but also (queer as this may sound) in judgements. This seems to abolish all logic, but does not do so.- It is one thing to describe methods of measurement, and another to obtain and state results of measurement. But what we call "measuring" is partly determined by a certain constancy in results of measurement. (Wittgenstein 1953, § 242)

Similarly, he might continue, our methods for assigning content to the words of others - for example, the standards we use for that purpose - are clearly distinct from our judgements to the effect that these words have a certain content. But the very existence of these methods of assessing linguistic content -i.e., the existence of a languagerests on agreement about a great number of more basic empirical judgments. ${ }^{36}$

Take the case of the builders as an example. If $A$ intends to be interpreted as ordering $B$ to fetch a building item and the latter wants to be interpreted as obeying that order, then interpreter and speakers must agree that the noises produced by $A$ instantiate the action of uttering a

35 Diamond 1975, pp. 200-201, 287.

36 About agreement on basic empirical judgement, see Wittgenstein 1978, VI: $\S 39$, where the example given is that of a judgement about the greenness of a certain object that is being pointed to. 
certain word, that some of the movements of $B$ 's body correspond to the action of going in a certain direction, that some of his other movements exemplify that of getting a certain building material and so on. This is the condition that must obtain if regularities like $(\mathrm{C})$ and hypotheses like $(\mathrm{H})$ are to be extracted from the behavior of $A$ and $B$. Of course the interpreter has to consider a much larger chunk of their deeds than that which is covered by a single hypothesis; otherwise each of the interpretive hypotheses would be strongly underdetermined by that chunk. According to Wittgenstein, the interpreter has to work out in the whole context of his interpretee's speech and deeds the language-game that the interpretee is playing - i.e. the set of linguistic rules he is following. Such a measure of holism is to be expected from an interpretive approach to meaning and to motive.

Other examples of this peaceful agreement in judgment, as Wittgenstein calls it, are: our judgements about whether the color of an object of ostension is the same as the color of another; whether the length of a rod which is presented to us is the same as the length of another. ${ }^{37}$ Overwhelming agreement in empirical judgement —or as in Davidson's interpretive account, extensive agreement in belief_-38 is indispensable for the identification of regularities in behavior of the kind that will lead to the proposal of interpretive hypotheses and of linguistic norms. ${ }^{39}$ To borrow a Davidsonian illustration: without a large-scale sharing of their basic empirical beliefs, there would be nothing, no complex belief for interpreter and interpretee to disagree about. A

37 Wittgenstein 1978, VI: $\S 21$.

38 See, for example, Davidson 1977.

39 The topic of the shared background of empirical judgement will be at the center of Wittgenstein's discussion in his last remarks (1969). It is also present in some passages of the second part of the Investigations. See, for example, Wittgenstein 1953, II: xi. 
person could not attribute beliefs to somebody else if they did not agree with each other about the majority of their beliefs.

So, for the communitarian theorist the criteria of correctness for what people mean by their words are constituted by the judgements of a certain linguistic community; if they use their own words the same way as the community does, then they are right in their judgements about what these words mean. Divergence from the communitarian judgment is in all cases synonymous with having gone wrong. The interpretive theorist, by contrast, does not think it necessary that speaker and interpreter use words in exactly the same way for the former to be counted as speaking a language. Some disagreement over their respective way with words may be harmless to communication provided that the speaker manages to make himself understood by his interpreter, i.e., is interpreted as he intended to be interpreted. And in order to get his intention across, the speaker must, in his behavior, present the interpreter with the clues that will allow the latter to grasp the norms of his linguistic practice. This requires, as we have seen, enough agreement in empirical judgement between speaker and hearer to sustain interpretive hypotheses about the content of the speaker's words. According to Wittgenstein, agreement in judgement requires, in turn, that speaker and hearer share a form of life. ${ }^{40}$ This means that speaker and hearer must be sufficiently similarly constituted beings so to react in roughly the same way in relevantly similar circumstances, to do roughly the same thing when prompted by roughly the same stimulus, etc. This is the biological or physical counterpart of the similarity in the content of their judgments.

40 Wittgenstein 1953, I: $\oint \S 19,23,241$; Wittgenstein 1953, II: xi; Wittgenstein 1978, VI: §34; Diamond 1975, pp. 182-184, 249. 
The interpretive criterion of linguistic correctness is therefore less demanding than the communitarian one; the speaker's prospective linguistic behavior will be assessed against the background of his linguistic practices, which he must render transparent to his interpreter if his goal is to communicate with him. Communitarian correctness requires more than overwhelming convergence of linguistic dispositions between the speaker and his hearer; for the communitarian theorist, the linguistic dispositions of the speaker must march in perfect step with those of his hearer.

5. The Social Aspect of Language for the Interpretive Wittgenstein

The above should suffice to deal with the second part of the puzzle mentioned in section 2, namely, that of reconciling Wittgenstein's dismissal of the community view with his claim that linguistic communication presupposes agreement in judgement between speaker and interpreter. My final aim is to describe the role of the social in the interpretive reading of Wittgenstein. His claim that a person who spoke only in monologue might still be interpreted suggests that Wittgenstein does not think a language can only exist when at least two people speak as the other does - the minimal community of two. ${ }^{41}$ This is not overshadowed by the remark -in paragraph 199 of the Investigations - that one person cannot follow a linguistic rule just once. The case of the monologue people shows that a single person could be said to speak a language; this predicate could not be attributed to him only in cases where he was observed to do something like it just once or very scarcely. But this is because the method of interpretation could not be applied in these cases.

41 Wittgenstein 1953, § 243. 
If speaking a language does not relevantly require sharing a complex practice of using words with somebody else (in the strict sense that the practices of speaker and hearer are exactly identical), then where, if at all, does the social enter the interpretive picture? For the interpretive theorist, no doubt a second person - the interpreter - is indispensable if a person - the speaker - is to speak a language; we saw that such a phenomenon cannot be accounted for from the perspective of the first person alone. But what must they share if the interpreter is to understand his subject? I take the interpretive Wittgenstein to claim that they must agree, firstly, on a large number of their empirical judgements. Innumerous utterances of "this is white" are in a vast majority of cases met with assent. They must agree, secondly, on their forms of life. According to Wittgenstein, this is tantamount to saying that subject and interpreter roughly coincide in the pattern of their intentional activities: the pattern of their counting is roughly the same and so is the pattern of their walking, etc. Finally, there must be sufficient agreement in their linguistic norms. Otherwise the speaker could never get his observer to interpret him as he intended to be understood; they would be disagreeing about the correct use of the words of the speaker.

This three-fold agreement is, I think, all Wittgenstein would allow as indispensable for explaining verbal communication. The assumption of a social linguistic practice (again in the strict sense of its being identical for speakers and hearers) would be both unnecessary and unrealistic for describing the phenomenon in question. What the above three-fold agreement demands is that their practices should by and large converge. The limiting case of the monologue people shows that it is possible to engage in a practice not shared, strictly speaking, by anyone else. An adequately positioned interpreter and his Robinson Cru- 
soe would need to converge a lot. But not to the extent that the language of the interpreter and Crusoe's should be identical.

\section{REFERENCES}

Cottingham, J., et al., 1984, The Philosophical Writings of Descartes, Vol. II, Cambridge University Press, Cambridge. Davidson, D., 1977, "The Method of Truth in Metaphysics" in Davidson 1984.

— 1980, "Towards a Unified Theory of Meaning and Action" in Grazer Philosophische Studien, vol. 2, pp. 1-12.

_ , 1982, "Expressing Evaluations", The Lindley Lecture, University of Kansas.

- 1984, Inquiries into Truth and Interpretation, Oxford University Press, Oxford.

—, 1990, "The Structure and Content of Truth" in The Journal of Philosophy, no. 87, pp. 279-328.

—, 1995, "Could There Be a Science of Rationality" in International Journal of Philosophical Studies, no. 3, pp. 116.

Descartes, R., 1641, Meditationes de Prima Philosophiae, English translation in Cottingham et al. 1984.

Diamond, C., 1975, Wittgenstein's Lectures on the Foundations of Mathematics, Cambridge 1939, The University of Chicago Press, Chicago.

Hopkins, J., 1995, "Wittgenstein, Davidson and Radical Interpretation" in: http://www.kcl.ac.uk/kis/schools/hums/philosophy /staff/wittdav.html/

Jeffrey, R., 1965, The Logic of Decision, McGraw-Hill, New York.

Kripke, S., 1982, Wittgenstein on Rules and Private Language, Harvard University Press, Cambridge.

McDowell, J., 1984, "Wittgenstein on Following a Rule" in Synthèse, no. 58, pp. 325-363.

Mellor, D. (ed.), 1990, F.P. Ramsey Philosophical Papers, Cambridge University Press, Cambridge. 
McGinn, C., 1984, Wittgenstein on Meaning, Basil Blackwell, Oxford.

Pinto, S., 1998, Wittgenstein, Meaning and Mathematics, Ph.D. dissertation, University of London, London.

Quine, W., 1960, Word and Object, the MIT Press, Cambridge. Ramsey, F., 1926, "Truth and Probability" in D. Mellor (ed.) 1990.

Tarski, A., 1933, "The Concept of Truth in Formalised Languages" in A. Tarski 1956.

—-, 1956, Logic, Semantics, Metamathematics, Oxford University Press, Oxford.

Wittgenstein, L., 1953, Philosophical Investigations, Basil Blackwell, Oxford.

— 1969, On Certainty, Basil Blackwell, Oxford.

- 1978, Remarks on the Foundations of Mathematics, 3rd. ed., Basil Blackwell, Oxford (First edition: 1956).

Wright, C., 1980, Wittgenstein on the Foundations of Mathematics, Harvard University Press, Cambridge.

Recibido: 8 de septiembre de 1999 


\section{RESUMEN}

En el presente trabajo intento resolver el conflicto aparente entre los aforismos finales de las observaciones sobre el seguimiento de reglas ( $\S \S 138$ a 243 de las Investigaciones filosóficas). En los párrafos 241-242, Wittgenstein afirma que la comunicación lingüística requiere un acuerdo entre los hablantes en relación con el idioma que hablan, lo que sugiere que el carácter social del lenguaje consiste justamente en el hecho de que todos los que lo usan de manera competente lo comparten esencialmente; sin embargo, lo enunciado en el párrafo siguiente (243) —la posibilidad de que un lenguaje tenga solamente un hablantepronto contradice esa idea. El ejemplo de lenguaje solitario que Wittgenstein ofrece es el de una persona que habla exclusivamente en monólogo. Si un lenguaje así es posible, entonces, ¿dónde residiría el aspecto social del lenguaje? Además de buscar una manera de disolver el mencionado conflicto entre los párrafos 241-242 y 243, procuro dar una respuesta wittgensteiniana a esta última pregunta.

En la sección 2 comienzo por acercar el problema wittgensteiniano de seguir reglas al escepticismo sobre el significado introducido por Kripke. Sostengo que ambos problemas contienen una dimensión constitutiva y una dimensión epistemológica. La primera se podría expresar de la siguiente manera: ¿qué es lo que constituye el seguimiento de una regla lingüística o el uso de una palabra con un determinado significado? La dimensión epistemológica del problema de seguir reglas se traduce en la cuestión de cómo conocemos nuestro propio seguir reglas lingüísticas y también el de las demás personas. Con estas distinciones es más fácil entender el argumento usado por Wittgenstein para rechazar la concepción privatista del seguimiento de reglas: tal concepción simplemente no da una respuesta satisfactoria a la cuestión constitutiva del problema. Se ha sugerido que la refutación del enfoque privatista sobre el significado habría llevado a Wittgenstein a adoptar una concepción comunitaria del significado, aunque muchos comentaristas han reconocido la existencia de evidencia textual contraria a tal propuesta exegética.

En la sección 3 defiendo la idea de que en las Investigaciones Wittgenstein propone una concepción intermedia sobre el sig- 
nificado y las reglas lingüísticas, la cual cae entre la posición privatista y el enfoque comunitario. Sostengo que el enfoque wittgensteiniano es interpretativo, aunque con rasgos que lo distinguen de la concepción quineana y, sobre todo, de la posición davidsoniana. Intento mostrar también que el interpretacionismo aquí atribuido a Wittgenstein no está de ninguna manera sujeto a la célebre paradoja de las interpretaciones ( $\S 201)$, ya que la noción de interpretación presente en la paradoja es distinta de la que conforma el enfoque interpretacionista wittgensteiniano.

En la sección 4 trato de establecer las semejanzas y las diferencias entre el enfoque comunitario y la concepción interpretativa. Presento el primer enfoque como si diera la siguiente respuesta a la cuestión constitutiva sobre el significado: la corrección del uso de las palabras está constituida por el uso que hace de su idioma un miembro de la comunidad lingüística. El criterio comunitario de corrección lingüística depende, por lo tanto, de los juicios de un observador externo. A pesar de que considera indispensable que haya acuerdo entre hablante y oyente respecto de muchos de sus juicios empíricos, la concepción interpretativa wittgensteiniana no toma tales juicios como constituyentes del significado lingüístico. El significado está constituido, según tal concepción, por nuestras prácticas interpretables.

Finalmente, en la sección 5 presento una respuesta a la pregunta sobre el aspecto social del lenguaje según el Wittgenstein interpretativo. Para que la actividad de una persona se pueda caracterizar como un lenguaje, es necesario que sea interpretable. Esto requiere, en primer lugar, un observador externo. Para que tal observador pueda interpretar al hablante, entonces, en segundo lugar, ambos tienen que estar más o menos de acuerdo respecto de la mayoría de sus juicios empíricos; en tercer lugar, tienen que ser lo suficientemente parecidos desde el punto de vista biológico; en cuarto lugar, tienen que coincidir más o menos en cuanto a los criterios de evaluación de la actividad lingüística del hablante. Este conjunto de condiciones conforma el carácter social del lenguaje para Wittgenstein, según mi interpretación; no obstante, dichas condiciones no exigen que la práctica lingüística sea estrictamente compartida en el sentido de que sea exactamente idéntica para todos los hablantes de un mismo "idioma". 